\title{
OPTIMIZATION OF OLIVE OIL, TWEEN 80, AND PROPYLENE GLYCOL OF SELF- NANOEMULSIFYING DRUG DELIVERY SYSTEM OF ZINC OXIDE BY D-OPTIMAL METHOD
}

\author{
Dian Eka Ermawati*), Wening Wulandari, Adi Yugatama \\ Department of Pharmacy, Sekolah Vokasi \\ Universitas Sebelas Maret, Surakarata, Indonesia
}

Received November 19, 2018; Accepted April 17, 2020

\begin{abstract}
The incidence of skin cancer in Indonesia reaches 6-8\%, so the skin needs effective protection. Zinc Oxide $(\mathrm{ZnO})$ is a sunscreen with Sun Protecting Factor (SPF) 50 which is able to reduce exposure to Ultraviolet rays. $\mathrm{ZnO}$ is difficult to dissolve in water making an obstacle if dispersed in a hydro gel matrix, so it is formulated into a Self-Nanoemulsifying Drug Delivery System (SNEDDS) preparation. SNEDDS formula was made using tween 80 as surfactant, propylene glycol as a co-surfactant, and olive oil. The optimum proportion of the three components was optimized with the D-Optimal method using Design Expert Stat-Ease 9 Trial software. Software obtained 16 formulas which were tested for physical stability response: transmittance value (\%) and $\mathrm{pH}$ value. SNEDDS optimum formula was compared with the DOptimal prediction formula using the student's t-test statistical analysis ( $p>0.05)$, the loading dose of $\mathrm{ZnO}$, Particle Size Analysis, and Zeta Potential. The optimum proportion of propylene glycol, tween 80, and olive oil making up SNEDDS were 9.9\%: 81\%: 9.1\% respectively. The result of the percent transmittance response was $92.30 \%$ and the $\mathrm{pH}$ value was 7.20. Software prediction results: transmittance value was $92.59 \%$ and $\mathrm{pH}$ value was 7.37. Statistical analysis of one sample t-test showed no difference between observations and D-Optimal predictions. SNEDDS was able to load $2.0 \mathrm{mg} \mathrm{ZnO/gram} \mathrm{SNEDDS} \mathrm{with} \mathrm{a} \mathrm{particle} \mathrm{size} \mathrm{of} 150.2 \mathrm{~nm}$; polydispersity index of 0.54 and zeta potential of $-28.50 \mathrm{mV}$. The SPF value of SNEDDS $\mathrm{ZnO}$ was 16.
\end{abstract}

Keywords: D-Optimal; SNEDDS; UV protective; ZnO.

\section{INTRODUCTION}

Indonesia is a tropical country that is crossed by the equator line. This situation causes the region of Indonesia to be always exposed to sunlight with high intensity, where the sunlight contains ultraviolet (UV). UV light A (320-400 nm) can penetrate the deeper layers of the skin to the dermis and could cause aging, pigmentation, erythema, tanning, and DNA damage due to the presence of reactive oxygen compounds or ROS (Reactive Oxygen Species). UV B (290-320 nm) could penetrate into top surface layer of the skin and cause DNA damage. Whereas UV C (100-290 $\mathrm{nm}$ ) could be filtered by the atmosphere and it could not penetrate to the surface of the earth (Cefali et al., 2016; Kulkarni et al., 2014). Human's skin, when getting too much exposure of UV rays for a long period, will be susceptible to cancer, sunburn, eye damage such as cataract and melanoma, premature skin aging, pigmentation, erythema, and also immune system damage (Lolo et al., 2017; Kockler et al., 2012).

World Health Organization (WHO) in 2015 estimated that the incidence of nonmelanoma cancer increased by 300.000 cases due to ozone depletion. The incidence of skin cancer in Indonesia reaches 6-8\% (Suharyanto and Prasetyo, 2004). Therefore, skin needs

*Corresponding Author: Dian Eka Ermawati

Email: dianekaerma@gmail.com 
protection against $\mathrm{UV}$ light. $\mathrm{ZnO}$ is one of the materials which are able to absorb the sun's spectrum with light quantum better than $\mathrm{TiO} 2$ which has an SPF value of 45-50 (Hutabarat, 2012). The SPF (Sun Protecting Factor) value has a range between 2 to $60 . \mathrm{ZnO}$ has an SPF value of 50 (Cosmetics Formulary, 2012). Dermatologists recommend using sunscreen at least at SPF 15-30 (Charisma, 2012) to protect skin from UV light. $\mathrm{ZnO}$ has a physical action by reflecting UV light.

$\mathrm{ZnO}$ powder is water insoluble and has a cloudy white physical appearance which is a problem if dispersed into a hydro gel matrix. Colloidal dispersion of $\mathrm{ZnO}$ is one of resolves to disperse $\mathrm{ZnO}$ into hydro gel matrix to form transparent appearance, and reduce the side effects of skin irritation when using $\mathrm{ZnO}$ with a concentration of more than $10 \%$ (Martorano, 2010). SNEDDS (Self-Nanoemulsifying Drug Delivery System) is a technique to reduce the particle size of water insoluble material such as $\mathrm{ZnO}$. SNEDDS is an isotropic mixture of oil, surfactant and co-surfactant that would form nanoemulsion of oil in water without stirring. The SNEDDS formula consist of olive oil, tween 80 as surfactant, and propylene glycol as co-surfactant. The oil requirement in the SNEDDS is medium-long chain oil such as candlenut oil, coconut oil and olive oil. Tween 80 is hydrophilic with Hydrophil Lipophil Balance (HLB) value of 15 and to get the result of percent transmittance value of SNEDDS preparations more than 90\% (Diba et al., 2014). The higer concentration of surfactant could decrease the particle size of $\mathrm{ZnO}$. Propylene glycol helps the surfactant to reduce the surface tension between oil and water so able to reduce the $\mathrm{ZnO}$ particle size.

The proportions of composition of olive oil, tween 80, and propylene glycol in SNEDDS formula are not yet known with certainty so optimization is performed. SNEDDS of $\mathrm{ZnO}$ formula optimization in this study was carried out using a D-Optimal mixture design (D-Optimal mixture design). D-Optimal is a method that is widely used in formulations, especially in cosmetics, pharmaceuticals, and food. The advantage of using the D-Optimal method is that it could reduce the number of experimental treatments (Borhan et al., 2014). In addition, the costs used are lesser due to the small number of experimental treatments (Zen et al., 2015).

\section{METHODS \\ Materials}

$\mathrm{ZnO}$ cosmetics grade (Zochem, Canada), distilled water, olive oil (Maroco), propylene glycol (DOW, New York), Tween 80 (Hercules).

\section{Compatibility test of $\mathrm{ZnO}$ with SNEDDS components}

Amount of $10.0 \mathrm{mg}$ of $\mathrm{ZnO}$ was added to Eppendorf which contained 5.0 grams of total system consisting of olive oil, tween 80 , and propylene glycol. The mixture was vortexed for 10 minutes then incubated in a shaker incubator at $45 \pm 2{ }^{\circ} \mathrm{C}$ for 15 minutes. Insoluble $\mathrm{ZnO}$ was separated by centrifuge at $5000 \mathrm{rpm}$ for 20 minutes. The supernatant formed was filtered and dissolved with ethanol. The test was carried out with replication of 3 times and analyzed with spectrophotometer UV-VIS (Khan et al., 2015). A solution that was visually clear and had a transmittance value of more than $80 \%$ was a compiler component of SNEDDS that was compatible with $\mathrm{ZnO}$. Distilled water was used as blank.

\section{Experimental design}

Determination of the upper and lower limits was done by comparison of oil: surfactant: co-surfactant starting from 1: 1: 1 to 1: 9: 1 with percent transmittance value as clarity parameters. The SNEDDS formula design was performed using Design Expert Stat-Ease 9 Trial software with the D-Optimal method. The main components of SNEDDS were oils (Olive oil), surfactants (Tween 80), and co-surfactants (Propylene glycol). The three criteria for free variables were set as the lower limit (low) and the upper limit (high) described in table 1. The responses tested including percent transmittance value (\%) and SPF values entered in the D-Optimal method using DX software. 
Table 1. Upper and lower limit value of SNEDDS formula entered in DX software

\begin{tabular}{lcc}
\hline \multicolumn{1}{c}{ Materials } & Lower limit $\mathbf{( \% )}$ & Upper limit $(\boldsymbol{\%})$ \\
\hline Olive oil & 9.09 & 11.11 \\
\hline Tween 80 & 77.77 & 81.81 \\
\hline Propylene Glycol & 9.09 & 11.11 \\
\hline
\end{tabular}

\section{Optimization of SNEDDS formula using D- Optimal method}

Software Design Expert Stat-Ease 9 Trial would design 16 formulas after determining the upper and lower limits of the components of the SNEDDS formula. All ingredients were weighed (Table 2), then $\mathrm{ZnO}$ with the prescribed dose was dissolved into the SNEDDS formula into flacon disk. The mixture was homogeneous with vortex for 3 minutes and sonicated for 10 minutes. This sonication method was carried out to help reduce the size of the emulsion droplets. The SNEDDS $\mathrm{ZnO}$ mixture was then incubated using water bath at temperature of $45^{\circ} \mathrm{C}$ for 15 minutes until homogeneous. SNEDDS was stored at room temperature during the characterization process (Savale, 2015; Ke et al., 2015).

\section{Physical responses of SNEDDS ZnO}

Transmittance Test (\%): amount of 1.0 $\mathrm{mL}$ SNEDDS was dissolved with redistilled water ad $50 \mathrm{~mL}$ at room temperature, then vortex for 3 minutes until homogeneous. Percent transmittance was measured using Spectrophotometer UV-VIS at maximum wavelength of $\lambda 650 \mathrm{~nm}$ with the redistilled water as a blank (Winarti et al., 2016). The $\mathrm{pH}$ Value Test: amount of $1.0 \mathrm{~mL}$ SNEDDS was dissolved with $9.0 \mathrm{~mL}$ redistilled water then the $\mathrm{pH}$ value was checked using $\mathrm{pH}$ meter.

\section{Loading dose of $\mathrm{ZnO}$ into SNEDDS formula}

The loading dose was determined by varying the amount of $\mathrm{ZnO}$ starting from $2 \mathrm{mg}$; $3 \mathrm{mg} ; 5 \mathrm{mg}$; $8 \mathrm{mg}$; and $10 \mathrm{mg}$ per gram of SNEDDS (total weight of SNEDDS formula was $5.0 \mathrm{~g}$ ) then dissolved at $50 \mathrm{~mL}$ redistilled water into disk at room temperature, then vortex for 3 minutes until homogeneous. Percent transmittance was measured using Spectrophotometer UV-VIS at maximum wavelength of $\lambda 650 \mathrm{~nm}$ with the redistilled water as a blank (Winarti et al., 2016). Mixture formula with high percent transmittance value was chosen as optimum loading dose of $\mathrm{ZnO}$ into SNEDDS.

\section{Optimum formula of SNEDDS ZnO}

The optimum formula of SNEDDS was determined using Design Expert Stat-Ease 9 Trial software with D-Optimal method. The SNEDDS formula consist of oil, surfactants and co-surfactants were evaluated by percent transmittance value (\%) and $\mathrm{pH}$ values. ANOVA statistical analysis with p-value $\leq$ 0.05 (Winarti et al., 2016; Gohel et al., 2016) for analysis and included into software, then characterization of optimum formula with software prediction was verified using one sample t-test analysis with IBM SPSS Statistics 22 software. The particle size distribution for the optimum formula of SNEDDS $\mathrm{ZnO}$ was also checked using a particle size analyzer (PSA) in the Nanotechnology Department of the Faculty of Mathematics and Natural Sciences, Islamic University of Indonesia, Yogyakarta. Amount of $1.0 \mathrm{~mL}$ SNEDDS $\mathrm{ZnO}$ was dissolved with redistilled water ad $50 \mathrm{~mL}$ then vortexed for 3 minutes until homogeneous. The emulsion formed was taken by $3.0 \mathrm{~mL}$ and was put into a cuvette for analysis. Replication was carried out 3 times for each test (Jevana and Sreelaksmi, 2011). The optimum SNEDDS $\mathrm{ZnO}$ was observed under SEM (Scanning Microscope Electron) to determine the distribution of $\mathrm{ZnO}$ nano particles into SNEDDS.

\section{RESULTS AND DISCUSSION}

Optimization of composition of olive oil: tween 80: propylene glycol was carried out to obtain the optimal proportion that was able to form colloidal dispersion so as to reduce the size of $\mathrm{ZnO}$ particles. The upper and lower limits of the concentration of each component were determined based on a preliminary test in 
order to obtain the optimum percentage range with the D-Optimal method using the Design Expert Stat-Ease 9 Trial software according to the desired criteria. Three components in determining the composition of the SNEDDS formula consisting of olive oil (A), tween 80 (B) surfactant, and propylene glycol (C) cosurfactant were determined as independent variables with percent transmittance values $(\%)$ and $\mathrm{pH}$ value as response variables. The independent variables that had been carried out in the previous orientation had lower limits and upper limits range of $9.09-11.11 \%(\mathrm{~A})$, $77.77-81.81 \%$ (B), and $9.09-11.11 \%$ (C ). The use of oil and co-surfactants to produce a good SNEDDS formula was less than $20 \%$ and surfactants reached 60\% (Cerpnjak et al., 2013). The results obtained from D-Optimal were 16 run formulas with different compositions of oil; surfactant; co-surfactant where the total of each component was $100 \%$ and total weight of SNEDDS formula was 5.0 grams.

The loading dose was carried out to determine the maximum amount of $\mathrm{ZnO}$ that could be dispersed into SNEDDS. ZnO loading dose test results that could be completely dispersed was at a dose of 2.0 $\mathrm{mg} / \mathrm{g}$ SNEDDS. ZnO was perfectly dispersed when it has clear visual appearance, homogeneous, and there are no deposits in SNEDDS. Propylene glycol is a co-surfactant that is often used in cosmetic preparations where the use of co-surfactants could reduce the flexibility of surface tension so that it has enough flexibility to form nanoemulsions with large compositions (Senapati et al., 2016).

Physical characteristics parameters include the percent transmittance value, where the higher value of percent transmittance which is close to the water transmittance value $(100 \%)$ indicates a smaller particle size (Ahmad et al., 2014). The results of percent transmittance value from 16 run formulas ranged from $54.75 \%$ to $95.02 \%$. The higher transmittance value indicated the smaller particle size, so the solution appearance was clear (Table 2). Clear visual appearance with transmittance value of more than $80 \%$ could be categorized as nanoemulsion (Fratter, 2016; Winarti et al., 2016). The $\mathrm{pH}$ value determines the chemical stability of the preparation and the suitability of the formula for the $\mathrm{pH}$ of the skin as to not to cause allergic reactions. The range of $\mathrm{pH}$ value from 16 run formulas were 4.0-7.5 indicating that SNEDDS $\mathrm{ZnO} \mathrm{pH}$ was suitable for the human skin (Gurning, 2016).

Experimental designs were often used in research designs because they provide maximum information with only requiring a small amount of experimentation. D-Optimal is a method that was used to optimize the proportion of components formula. The amount of olive oil (A), surfactant: tween 80 (B), and co-surfactant: propylene glycol (C) were chosen as the independent factor. The mixture profile was determined by D-Optimal based on the Bolton equation, where $\mathrm{Y}$ was the response, $\mathrm{ABC}$ were the proportion of the components, and $\alpha$ was the coefficient:

$$
\mathrm{Y}=\alpha 1(\mathrm{~A})+\alpha 2(\mathrm{~B})+\alpha 3(\mathrm{C})+\alpha 12(\mathrm{~A})(\mathrm{B})+\alpha 13(\mathrm{~A})(\mathrm{C})+\mathrm{A} 23(\mathrm{~B})(\mathrm{C})+\alpha 123(\mathrm{~A})(\mathrm{B})(\mathrm{C}) \ldots .
$$

Table 2. Results of formula analysis with D-Optimal method using DX Stat-Ease 9 Trial software that produced 16 run formulas and response parameters of physical properties: percent transmittance and $\mathrm{pH}$ value

\begin{tabular}{|c|c|c|c|c|c|}
\hline Run & $\begin{array}{l}\text { Olive Oil } \\
(\%)\end{array}$ & Tween $80(\%)$ & $\begin{array}{c}\text { Propylene glycol } \\
(\%)\end{array}$ & $\begin{array}{c}\text { Transmittance } \\
(\%)\end{array}$ & pH \\
\hline 1 & 10.11 & 80.81 & 9.09 & 68.11 & 7.34 \\
\hline 2 & 10.10 & 78.79 & 11.11 & 66.59 & 7.33 \\
\hline 3 & 9.09 & 79.80 & 11.11 & 95.02 & 7.27 \\
\hline 4 & 9.09 & 80.81 & 10.11 & 94.28 & 7.53 \\
\hline 5 & 11.11 & 79.80 & 9.09 & 69.05 & 7.42 \\
\hline 6 & 11.11 & 78.79 & 10.10 & 62.28 & 7.40 \\
\hline
\end{tabular}




\begin{tabular}{|c|c|c|c|c|c|}
\hline Run & $\begin{array}{l}\text { Olive Oil } \\
(\%)\end{array}$ & Tween $80(\%)$ & $\begin{array}{c}\text { Propylene glycol } \\
(\%)\end{array}$ & $\begin{array}{c}\text { Transmittance } \\
(\%)\end{array}$ & pH \\
\hline 7 & 9.50 & 81.00 & 9.50 & 90.44 & 7.29 \\
\hline 8 & 11.11 & 77.78 & 11.11 & 81.70 & 7.54 \\
\hline 9 & 11.11 & 77.78 & 11.11 & 81.81 & 7.55 \\
\hline 10 & 10.00 & 79.50 & 10.51 & 63.82 & 6.82 \\
\hline 11 & 11.11 & 79.80 & 9.09 & 69.29 & 7.61 \\
\hline 12 & 9.09 & 81.81 & 9.10 & 89.56 & 7.58 \\
\hline 13 & 11.11 & 78.79 & 10.10 & 63.89 & 7.41 \\
\hline 14 & 9.90 & 80.20 & 9.90 & 54.75 & 6.91 \\
\hline 15 & 9.09 & 79.80 & 11.11 & 82.87 & 7.43 \\
\hline 16 & 9.09 & 81.81 & 9.10 & 89.71 & 7.68 \\
\hline
\end{tabular}

*SNEDDS system with 5.0 grams amount

Anova is a statistical analysis that explains about the percent transmittance response with cubic models and $\mathrm{pH}$ with quadratic models. The model shows the effect of using the composition of oil phase, surfactant, and co-surfactant of each formula which has significant differences that could be known from the ANOVA analysis contained in the software $(p>0.05)$. Table 3 showed the mixture of oil, surfactants and co-surfactants to the transmittance response parameters and $\mathrm{pH}$ value of SNEDDS, where there was an interaction between olive oil, tween 80 and propylene glycol which the highest value was propylene glycol with the value of -4513.94 , it means that concentration of propylene glycol could decrease the transmittance value. The combination of the three components in mixture formula also provided a response to decrease the transmittance value. This was possible because $\mathrm{ZnO}$ component can refract the light during the transmittance test using the spectrophotometry UV-VIS method. The $\mathrm{pH}$ value response parameter has a quadratic model where there was an interaction between two components in the mixture with the highest response value was oil that valued of +27.56 , it means that concentration of oil would increase the $\mathrm{pH}$ value.

The numbers in the triangle show the composition of oil, surfactants and cosurfactants in the modeling. The highest response is shown in the red area; the lower response is shown in the yellow area and the lower one is in the green and blue area (Figures 1 and 2). The solution chosen was the one with the highest desirability value that was closed to 1.0, result of software analysis based on the chosen criteria was 0.84 meaning that the formula would produce physical characteristics which was optimal according to the desired target. The proportion of the optimum composition of oil, surfactant and co-surfactant was 9.1\%: 81\%: $9.9 \%$.

Table 3. Results of software analysis into mathematics model based on physical properties and ANOVA statistical

\begin{tabular}{cccc}
\hline $\begin{array}{c}\text { SNEDDS response of } \\
\text { physical properties }\end{array}$ & \multicolumn{1}{c}{ Mathematics Equation } & $\begin{array}{c}\text { Mathematics } \\
\text { Model }\end{array}$ & $\begin{array}{c}\boldsymbol{p} \text {-value } \\
\text { [ANOVA] }\end{array}$ \\
\hline $\begin{array}{c}\text { Percent transmittance } \\
(\%)\end{array}$ & $\begin{array}{l}\text {-3652.73(A)-111.78(B)- } \\
4513.94(\mathrm{C})+52.39(\mathrm{~A})(\mathrm{B})+523.42(\mathrm{~A})(\mathrm{C})+6\end{array}$ & Cubic \\
& $3.31(\mathrm{~B})(\mathrm{C})-6.78(\mathrm{~A})(\mathrm{B})(\mathrm{C})$ & 0.053 \\
\hline $\mathbf{p H}$ & $27.56(\mathrm{~A})+0.70(\mathrm{~B})+14.70(\mathrm{C})-0.35(\mathrm{~A})(\mathrm{B})-$ & \multirow{2}{*}{ quadratic } & 0.077 \\
& $0.45(\mathrm{~A})(\mathrm{B})-0.18(\mathrm{~B})(\mathrm{C})$ & &
\end{tabular}



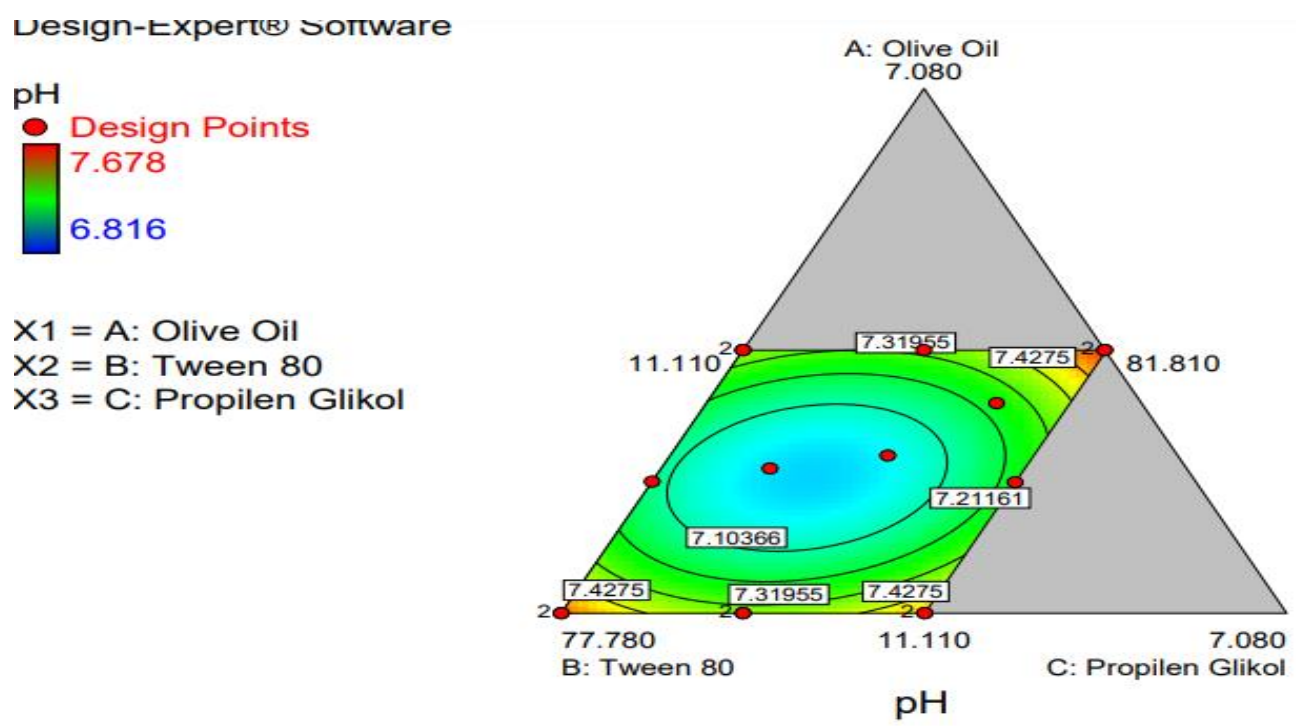

Figure 1. Results of Contour plot diagram showed that the optimum $\mathrm{pH}$ response parameter area was in the range of 6.82-7.68 with red color area
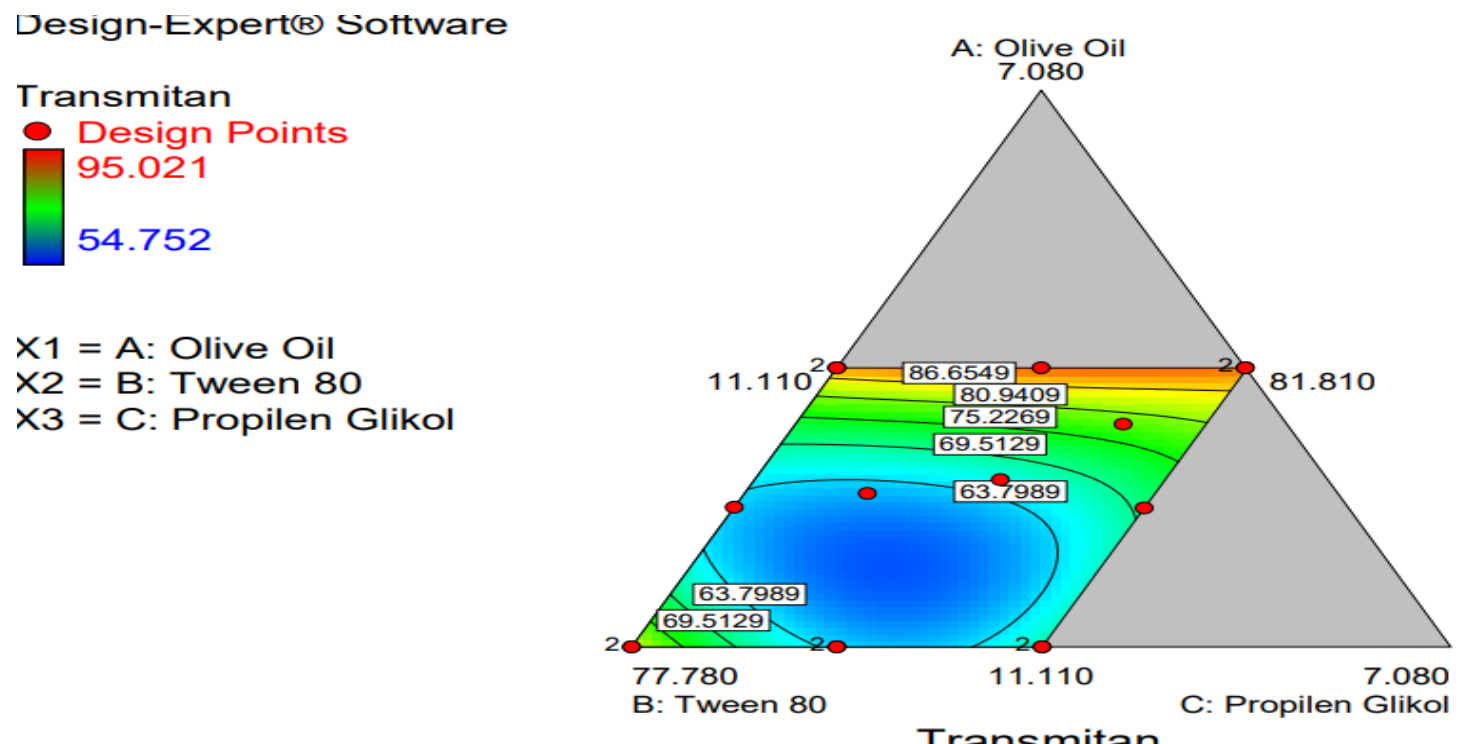

Transmitan

Figure 2. Results of Contour plot diagram showed that optimum percent transmittance response parameter area was almost $95.02 \%$ with red color area

Table 4. Results of observation value of SNEDDS ZnO optimum formula compared with Software

\begin{tabular}{cccc}
\hline $\begin{array}{c}\text { Respons of physical } \\
\text { properties }\end{array}$ & $\begin{array}{c}\text { Prediction value } \\
\text { Drept } \\
\text { prediction }\end{array}$ & $\begin{array}{c}\text { Observation } \\
\text { results }\end{array}$ & Sig-value \\
\hline Transmittance (\%) & 92.59 & 92.30 & 0.053 \\
\hline pH & 7.37 & 7.20 & 0.077 \\
\hline
\end{tabular}

The software predicted value which was obtained from the D-Optimal method shows that the confidence level of prediction interval of $95 \%$ if compared with the response value of the observations for the optimal formula using statistical analysis. The criteria that were given were maximized for percent transmittance value and target for $\mathrm{pH}$ value. Based on the test results as presented in table 4, the response percentage of transmittance (clarity) 
and $\mathrm{pH}$ value from the observation of the optimal formula did not differ significantly from the predicted values given by the Design Expert Stat-Ease 9 Trial software (pvalue $>0.05)$.

\section{Measurement of particle size and zeta potential of SNEDDS $\mathrm{ZnO}$ optimum formula}

The nanoemulsion droplet size of $\mathrm{ZnO}$ into SNEDDS was $150.2 \mathrm{~nm}$ with a polydispersity index value of 0.54 . The recommended PI value requirements indicate that the particles in the SNEDDS formula are stable and reduce the possibility of deposition because brown motion of $\mathrm{ZnO}$ particles are rapidly. PI values that meet the observed PI value was quite good and still met the good PI standard value.

PI in particle measurement was used to describe the homogeneity of nanoemulsion particles which have a range of 0.0 to 1.0 (Pratiwi et al., 2016). The small particle size could increase the surface area of the particle so it could increase absorption of the drug when it was applied on skin surface area. Nano size in the droplets would reduce the time of emulsification (Bandyopadhyay et al., 2012).

Low polydispersity index value shows a narrow particle size distribution meaning that the particle size in the SNEDDS was uniform (Avachat and Patel, 2014). Uniform particle size could increase homogeneity of $\mathrm{ZnO}$ when dispersed into SNEDDS and would be also absorbed faster with relatively the same speed (Balakumar et al., 2013). The potential zeta value obtained from SNNEDS $\mathrm{ZnO}$ was -28.5 $\mathrm{mV}$. SNEDDS with the potential zeta value in range of more than $+30 \mathrm{mV}$ and less than -30 $\mathrm{mV}$ would produce relatively stable preparations.
This negative potential zeta value indicates that the SNEDDS formula has a negative charge and it was sufficient to counteract the repulsive force so that it would produce a stable preparation (Dash et al., 2015). The range of potential zeta values to maintain stability was less than $-30 \mathrm{mV}$ or more than +30 .

Sun protective factor (SPF) value and scanning electron microscope (SEM) of SNEDDS ZnO optimum formula

SEM results at 100 times magnification showed that $\mathrm{ZnO}$ powder had an irregular surface shape and formed an aggregate, whereas on SNEDDS $\mathrm{ZnO}$ showed smaller particle sizes and uneven agglomerated in SNEDDS. The smaller the particle size would increase the specific surface area of the particle, thereby increasing the particle distribution (Figure 3). The SNEDDS formula (olive oil: tween 80: propylene glycol) has an $\mathrm{SPF}$ value of 5.0 while SNEDDS $\mathrm{ZnO}$ has an SPF value of 16. Research Idaho (2008) stated that sunscreen was recommended at least 15 minutes that a person has natural resistance to sunlight for 30 minutes (Moore, 1982). 

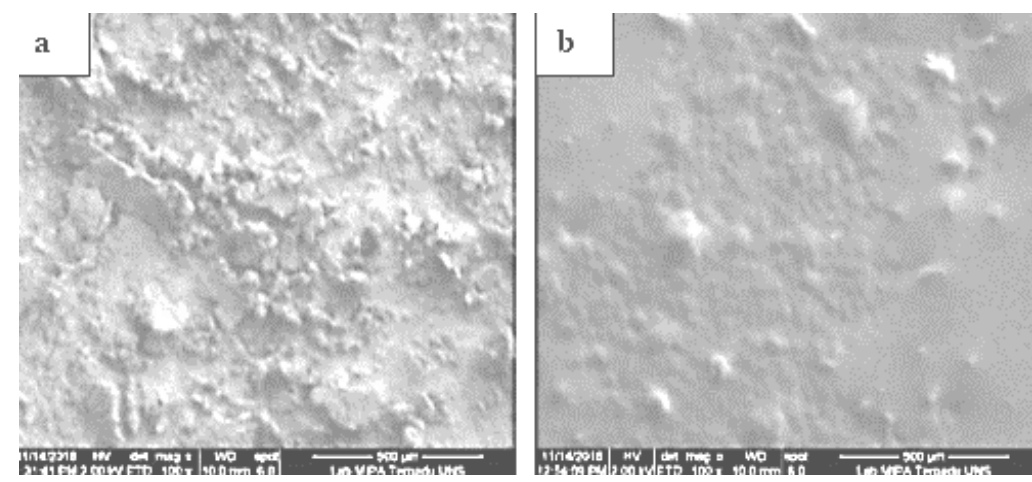

Figure 3. Results of SEM analysis using carbon coating. ZnO powders (a); SNEDDS ZnO (b) at 100 times magnification showed that $\mathrm{ZnO}$ powder had an irregular surface shape and formed an aggregate, whereas on SNEDDS ZnO showed smaller particle sizes and uneven agglomerated in SNEDDS

\section{CONCLUSION}

The optimum proportion of composition based on D-Optimal method with physical characteristics of transmittance and $\mathrm{pH}$ value was olive oil: tween 80: propylene glycol of 9.1\%: $81 \%$ : $9.9 \%$ where the interaction of olive oil and propylene glycol would increase the transmittance value but reducing the $\mathrm{pH}$ value. SNEDDS $\mathrm{ZnO}$ optimum formula result of the percent transmittance value was $92.30 \%$ and $\mathrm{pH}$ value of 7.2. D-Optimal prediction value for percent transmittance value was $92.59 \%$ and $\mathrm{pH}$ value of 7.37 . The results of the one sample t-test statistical analysis showed that there was no difference between the observations and D-Optimal predictions value. SNEDDS optimum formula was capable load of $10 \mathrm{mg} \mathrm{ZnO}$ particle with SPF value of 16 . The particle size of SNEDDS $\mathrm{ZnO}$ was $150.2 \mathrm{~nm}$; polydispersity index of 0.54 ; zeta potential of $-28.50 \mathrm{mV}$; and SPF value of 16. As further studies, SNEDDS ZnO would be dispersed into the hydrogel for topical preparations that is used as UV Protection.

\section{ACKNOWLEDGEMENT}

Mandiri Aktif Research Grant from LPPM (Lembaga Penelitian dan Pengabdian Masyarakat) Universitas Sebelas Maret 2018.

\section{REFERENCES}

Borhan, F.P., Gani, S.S., Shamsuddin, R. 2014. The Use D-Optimal Mixture
Design in Optimising Okara Soap Formulation for Stratum Corneum Application. The Scientific World Journal, (173979), 1-8.

Cefali, L.C., Ataide, J.A., Moriel, P., Foglio, M.A., Mazzola, P.G. 2016. Plant Based Active Photoprotectants Winarti for Sunscreens, International Journal of Cosmetic Science, 38(4), 346-353.

Charisma, S.L. 2012. Daya Tabir Surya dan Antioksidan Formula Krim Ekstrak Rimpang Kencur (Kaempferia galanga L.) dan Rimpang Temu Kunci (Boesenbergia pandurata (Roxb.) Schlecht), Universitas Muhammadiyah Purwokerto, Purwokerto.

Cerpnjak, K., Zvonar, A., Gasperl, M., Vrecer, F. 2013. Lipid-based System as a Promising Approach for Enhancing the Bioavailability of Poorly Water-Soluble Drugs. Acta Pharmaceutica, 63, 427-445.

Dash, R.N., Habibuddin, M., Humaira, T., Ramesh, D. 2015. Design, Optimization and Evaluation of Glipizide Solid SelfNanoemulsifying Drug Delivery for Enhanced Solubility and Dissolution, Saudi Pharmaceutical Journal, 23(5), 528-540.

Diba, R.F., Yasni, S., Yuliani, S. 2014. Nanoemulsifikasi Spontan Ekstrak Jintan Hitam dan Karakteristik Produk Enkapsulasinya (Spontaneous Nanoemulsification of Black Cumin Extract and the Characteristics of 
Encapsulation Product), Jurnal Teknologi dan Industri Pangan, 25(2), 134.

Gohel, M., Purohit, A., Patel, A., Hingorani, L. 2016. Optimization of Bacoside A. Loaded SNEDDS Using D-Optimum Mixture Design for Enhancement Insolubility and Bioavailability, International Journal of Pharmacy and Pharmaceutical Sciences, 8(12), 213-220.

Gurning, H.E.T. 2016. Formulasi Sediaan Losio Dari Ekstrak Kulit Buah Nanas (Ananas Comosus L.(Merr)) Sebagai Tabir Surya. Pharmacon, 5(3), 23022493.

Hutabarat, R. 2012. Sintesis dan Karakteristik Fotokatalis $\mathrm{Fe}^{2+-} \mathrm{ZnO}$ Berbasis Zeolit Alam, Universitas Indonesia, Jakarta.

Idaho. 2008. Sunscreen and Skin Self-Checks Frequently Asked Questions, Department Of Health and Welfare.

Jeevana, J.B., Sreelakshmi, K. 2011. Design and Evaluation of Self-Nanoemulsifying Drug Delivery System of Flutamide. Journal of Young Pharmacists, 3(1), 1-4.

Lolo, W.A., Sudewi, S., Edy, H.J. 2017. Determination Sun Protecting Factor (SPF) Of Krokot Herbs Extract (Portulacaoleracea L.), Journal of Pharmaceutical Science and Clinical Research, 2(1), 1-5.

Martorano, L.M., Stork, C.J., Li, Y.V. 2010. UV Irradiation- Induced Zinc Dissociation from Commercial Zinc Oxide Sunscreen and Its Action in Human Epidermal Keratinocytes, Journal of cosmetic dermatology, 9(4), 276-286.

Moore, W. 1982, Harry's Cosmeticology (7th ed), Godwin, 3(6), 247-254.

Patel, J., Patel, A., Raval, M., Sheth, N. 2011. Formulation and Development of a SelfNanoemulsifying Drug Delivery System of Irbesartan, Journal of Advanced Pharmaceutical Technology and Research, 2(1), 9-15.

Pratiwi, L., Fudholi, A., Martien, R., Pramono, S. 2017. Self-Nanoemulsifying Drug Delivery System (SNEDDS) for Topical Delivery of Mangosteen Peels (Garcinia Mangostana L.,): Formulation Design and
In Vitro Studies. Journal of Young Pharmacists, 9(3).

Rowe, R.C., Shesky, P.J., Quinn M.E. 2009. Handbook of Pharmaceutical Exipients. London: Pharmaceutical Press.

Sarker, A., Shimu, I.J.S., Tuhin, R.H., Raju, A.A. 2015. Nanoemulsion: An Excellent Mode for Delivery of Poorly Soluble Drug through Different Routes. Journal of Chemical and Pharmaceutical Research, 7(12), 966-976.

Savale, S.K. 2015. A Review - Self Nanoemulsifying Drug Delivery System (SNEDDS). International Journal of Research in Pharmaceutica and Nano Sciences, 4(6), 385-397.

Saryanti, D. 2016. Optimasi SelfNanoemulsifying Drug Delivery System Ekstrak Akar Purwoceng Gunung (Artemisia lactiflora wall ex. DC) dan Uji Absorpsi secara In Vitro. Fakultas Farmasi Universitas Gadjah Mada, Yogyakarta.

Setyorini, H.A., Kurniatri, A.A., Adelina, R., Winarsih. 2016. Karakterisasi Mutu Ekstrak Daun Sirsak (Annona muricata L.) dari Tiga Tempat Tumbuh. Buletin Penelitian Kesehatan, 44(4), 279-286.

Shibula, K., Velavan, S. 2016. Determination of Bioactive Compounds in Annona muricata Leaf Extract. Journal of Bioscience and Technology, 7(3), pp. 762-768.

Suharyanto, B. Prasetyo, R. 2004. Melanoma Maligna dan Permasalahannya. Berkala Ilmu Penyakit Kulit dan Kelamin FK UNAIR, 16(2).

Suliatin, T. 2017. Optimasi Formula Self Nano-Emulsifying Drug Delivery System (SNEDDS) Tetrahidrokurkumin menggunakan D-Optimal Design. Fakultas Farmasi, Universitas Muhammadiyah Purwokerto, Purwokerto.

Winarti, L., Martien, R., Suwaldi, Hakim, L. 2016. An Experiment Design of SNEDDS Template Loaded with Bovine Serum Albumin and Optimization Using D-Optimum. International Journal of 
Pharmaceutical and Clinical Research, $8(5), 425-432$.

Yulianti, E., Adelsa, A., Putri, A. 2016. Penentuan nilai SPF (Sun Protection Factor) Ekstrak Etanol $70 \%$ Temu Mangga (Curcuma mangga) dan Krim Ekstrak Etanol 70\% Temu Mangga (Curcuma mangga) secara In Vitro
Menggunakan Metode Spektrofotometri. Majalah Kesehatan FKUB, 2(1).

Zen, N.I.M., Gani, S.S.A., Shamsudin, R., Masoumi, H.R.F. 2015. The Use of DOptimum Mixture Design in Optimizing Development of Okara Tablet Formulation as a Dietary Supplement. The Scientific World Journal, 1-7 